\title{
Emergency Medical Service Reference Model for Low Impact and High Frequent Disaster in Indonesia
}

\author{
Nur Budi Mulyono ${ }^{1}$, Akbar Adhi Utama ${ }^{2}$, Noorhan Firdaus Pambudi ${ }^{3}$, Marina Natalia Tampubolon ${ }^{4}$, Niken \\ Larasati $^{5}$, Layung Anindya Prasetyanti ${ }^{6}$ \\ 1,2,3,4,5,6 Institut Teknologi Bandung \\ nurbudi@sbm-itb.ac.id \\ akbar@sbm-itb.ac.id \\ noorhan.firdaus@sbm-itb.ac.id \\ marina.natalia@sbm-itb.ac.id \\ niken.larasati@sbm-it.ac.id \\ layung.anindya@sbm-itb.ac.id
}

\begin{abstract}
Located in archipelago and intersection of 3 tectonic plates, Indonesia susceptible to the low impact and high frequency types of disaster such as flood, fire, landslides etc. These disaster types unexpectedly create more economic losses and disturb stability of social and economic order since less preparation and lack of reference model. One of the important humanitarian aid of catastrophic event like disaster is healthcare distribution system. This study aims to find out an appropriate emergency medical service (EMS) model for developing country like Indonesia considering nature of low impact and high frequency disaster. The EMS has two famous reference model: Anglo American and Franco German with the difference in the flow of medical doctor, ambulance, medical equipment, and the use of medicine. We conduct a deductive assessment of those two reference model and create recommendation of suitable EMS model for developing countries like Indonesia. The disaster's stakeholder such as National Board of Disaster Countermeasure (BNPB), Indonesian Red Cross (PMI), hospital and any other organizations involved in health care aids services can take benefit of our recommendation.
\end{abstract}

Keywords: healthcare aid, disaster, reference model, emergency medical service, Indonesia

\section{Introduction}

As the world has been witnessing an improvement of life quality, the importance of emergency medical service for emergency, disaster, and catastrophic conditions is getting more recognition nowadays. Disasters, both natural and manmade disasters, have high dependency on emergency medical services. Therefore, humanitarian logistics covering logistics aid for vulnerable people, in which disaster healthcare is included (Tomasini \& Wasenhove, 2009; Kovacs \& Spens, 2007), also had been gaining considerable attention.

As a result, there has been needs for emergency medical service as well as humanitarian aid logistics for events of disaster. While humanitarian logistics could partly rely on social and volunteer activities, emergency medical service fully rely on the involvement of local government or the municipals. Therefore, building reliable emergency medical service to response immediate disaster is a must for the citizen, rather than rely on the one operated by volunteers. As a matter of fact, even without specifically stated on its dedication to disaster response, basic models of emergency medical service had been maturely developed and find implementation in many areas.

There are two famous emergency medical service models used in many countries. Franco-German model, in which physicians are deployed to the emergency field, is widely adopted in European countries, such as Germany, France, Greece, Malta, and Austria (Al-Shaqsi, 2010). On the other hand, Anglo-American model, in which patients are to be brought to hospital as soon as possible, could be 
found in Unit. States, Canada, New Zealand, Oman, and Australia (Al-Shaqsi, 2010).

Nevertheless, both Franco-German and Anglo-American model might have different procedures to face emergency conditions, between ones caused by large scale disaster and another ones caused by small scale disasters. Previous studies suggest that disaster with small scale could actually bring high impact of damage when considering the frequency. Therefore, this research will focus on these so-called small scale disasters with high frequency. Here, we limits the type of disaster to: flood, hurricane, small scale earthquake, and landslide.

Being an archipelago, between two oceans, on intersection of three tectonic plates, and lying right on equator, makes Indonesia vulnerable to disasters. Island of Sumatra is one of the islands in Indonesia that has high possibility of having natural disasters, especially earthquake and tsunami. On the other hand, Java island as the most inhabited island in Indonesia, bear the risk of both natural and manmade disasters, especially the small scaled ones. According to data, disasters in West Java is dominated by hurricane, landslide, and flood.

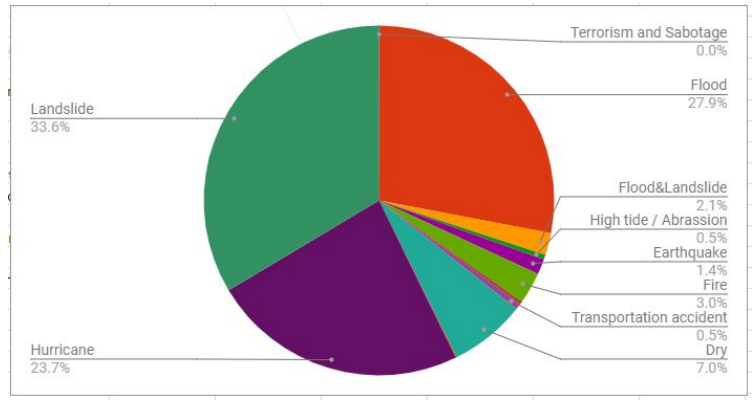

Figure 1. Disasters in West Java in the Last Ten Years

It is clear from Figure 1 that West Java are vulnerable to various kinds of disasters. Hurricane, landslide, and flood are the top three disasters occurs in West Java in the last ten years. These top three disasters contributed to more than $80 \%$ disasters in West Java. Besides those, West Java also bear the risk of fire, forest fires, earthquake, tsunami, etc.
Considering that either hurricane, flood, or landslide are included in small scaled disaster, we believe that emergency medical service is highly needed in Indonesia. However, the existence of sound emergency medical service for disasters has not been found yet. Healthcare facilities operate with their own management standard and procedure without guided by uniforms standard in a specific area.

This research aims to develop emergency medical service for disasters in Indonesia considering currently exist response system for disaster mitigation. As reference model, we will use the two previously mentioned basic model of emergency medical service. The suitability of the basic models will be further evaluated to find best model for developing countries especially Indonesia. The model should also be used as an emergency medical service for other developing countries susceptible to any kind of disaster and catastrophic events.

\section{Literature Review}

A supply chain is essentially a network consisting of suppliers, manufacturers, distributors, retailers and customers that manage material flows, information flows and financial flows (Wassenhove, 2005). The difference between supply chain in business context and supply chain in disaster will face uncertainty, like when, where, what, how much, where from and how many times to procure and distribute to disaster area. When disaster strikes, supply chain for aid needs to be manage to help victims in disaster area by helping hand from humanitarians in their operations.

\subsection{Humanitarian Supply Chain}

Humanitarian supply chains provide the response to disasters. The definition of humanitarian supply chain is derived from the definition of basic supply chain, "a set of approaches utilized to efficiently integrate suppliers, warehouses, and stores, so that merchandise is produced and distributed at the right quantities, to the right locations, and at the right time; in order to minimize system wide costs while satisfying service level requirements". This concept can be used in the humanitarian supply chain when applied in the disaster relief and excluding the term "customer" or "store" (Yadav \& Barve, 2015) 
Thomas and Kopczak (2005) from The Fritz Institute define there are seven activities include in the humanitarian supply chain, such as preparation, planning, procurement, transportation, storage, tracking and custom clearance. The difference between supply chain for business purpose with humanitarian supply chain is the main focus. Supply chain in humanitarian needs to be flexible and able to respond quickly to unpredictable events effectively (between life and death) and efficiently (treating great number of victims) under heavy budget constraints (Heasilp et al, 2010; Costa et al, 2012).

Humanitarian supply chain consist of more than just humanitarian organization. The list goes to donors, aird agencies, NGOs, governments, the military, logistic service providers and suppliers as the main actors in HSC. (Sahebi et al, 2016)

\subsection{Humanitarian Aid Logistic}

Logistics is an important factor in humanitarian aid operations, to the extent that logistics effort account for 80 percent of disaster relief (Trunick, 2005; Kovacs \& Spens, 2007). Delivering humanitarian aid needs to be in rapid response to serve the disaster victims and minimizing the impacts.

Logistic operations in humanitarians is the processes and systems involved in mobilizing people, resources, skills and knowledge to help vulnerable people affected by disaster (Wassenhove, 2006). Humanitarian logistics is an umbrella term for a mixed array of operations ( Kovacs \& Spens, 2007). The Fritz Institute (2004) defined humanitarian logistic as "tasks, all the process of planning, implementing and controlling the efficient, cost-effective flow and storage of goods and materials as well as information, from the point of origin to the point of consumption for the purpose of meeting the beneficiary's requirements and alleviate the suffering of vulnerable people (Vitoriano et al, 2013)

The purpose of humanitarian aid logistic to aid people in their survival. There are two main streams of humanitarian logistics that can be distinguished named as continuous aid work and disaster relief.
While the focus of disaster relief operations is to design the transportation of first aid material, food, equipment and rescue personnel from supply points to a larger number of destination nodes geographically scattered over the disaster region and the evacuation transfer of people affected by the disaster to the health care centers safely and very rapidly (Barbarosoglu et al, 2002; Kovacs \& Spens, 2007). ).

Humanitarian aid logistic focus on delivering rescue team and goods. In disaster relief, the most needed goods by disaster victims such as water, medicine, chlorination tablets, tents, blankets and protein biscuits for malnourished children (Dignan, 2005; Kovacs \& Spens, 2007). The procurement process of humanitarian aid including healtcare is separated into three phases according to disaster life cycle, preparedness, response and recovery.

Vaillancourt (2011) mentioned the first phase is planning the emergencies and prepare the relevant materials for different types of needs into kits. The phase continue to deliver the goods to the people in need, the second phase. This phase can be somewhat challenging due to infrastructure and unpredictable demand. In the response phase might focus on different needs and thus there exists a multitude of kits such as medical, educational, water and sanitation and household. The last phase is aim to enables the postponement of inventory allocations to specific countries (Scholten et al, 2010).

To reduce the great number of victims, the Emergency Medical Service (EMS) is employ during the second phase of disaster, in the response phase. EMS can be defined as "a comprehensive system which provides the arrangements of personnel, facilities and equipment for the effective, coordinated and timely delivery of health and safety services to victims of sudden illness or injury. (Al-Shaqsi, 2010). EMS is really helpful and beneficial during the disaster because it is an integral part of any effective and functional health care system that serve medical and trauma emergencies utilizing advanced clinical technology. 


\subsection{Disaster in West Java}

West Java was chosen for a case study as it has been well explored for natural disaster research and high potential frequent for natural disaster. This province has historical natural disaster record such as landslides, hurricane, flood, volcano eruption, earthquake and tsunami. Heavy landslide events occurred in West Java area closed to Bandung city in 2005 after 3 days heavy rain in dumpsite area (Koelsch et al., 2005). In 2006, tsunami struck on the south coast of West Java Province trigger by earthquake 7.7 Magnitude (Muhari et al., 2007). This province also hit by an earthquake 7.4 on the Richter scale on 2009, this earthquake triggering landslide crease great number of casualties in Cianjur Regency (Bisri, 2013). Earthquake activity is frequently recorded in West Java area due to volcano and geological activity (Carranza, 2008).

This province has potential high frequent disaster and have widely area to study emergency medical response during disaster. While many research in humanitarian aid logistics have been dedicated to solve problem of large scale disasters, this research will focus on small disasters with high frequency. Furthermore, this research will focus on the case of Indonesia, using West Java as preliminary study.

\section{Reference Model}

There are two well-known model implemented in Emergency Medical Services system, called as the Franco-German model and the Anglo-American model. The Franco-German model of EMS delivery is based on the "stay and stabilize" philosophy (Huiyi, 2007). In the Franco-German model, physicians and technology are sent to the scene in the hope of providing a higher level of emergency care before the patient's arrival at the hospital (Arnold, 1998). Figure 2 illustrates medical service process of Franco-German model.

On the other hand, the Anglo-American model is based around "scoop and run" philosophy (Dick, 2003). Here, patients are brought to hospital-based emergency departments so that they may be provided a higher level of care (Arnold, 1998). Figure 3 illustrates medical service process of Anglo-American model.

Arnold (1998) argued that most countries develops new emergency care systems in recent years following the Anglo-American model, as exemplified by emergency medicine in the United States. However, there is no comparative multinational studies exist to demonstrate the superiority of one model over the other. Critics have noted several problems with the Franco-German model: Physicians are not well trained, not well supervised, and not subject to the same quality-assurance controls as physicians in Anglo-American systems (Arnold, 1998). Table 1 provides several differences between those models.

Table 1. Comparison between Franco-German model and Anglo-american model (source: Al-Shaqsi, 2011)

\begin{tabular}{|l|l|l|}
\hline Model & $\begin{array}{l}\text { Franco-German } \\
\text { Model }\end{array}$ & $\begin{array}{l}\text { Anglo-America } \\
\text { n Model }\end{array}$ \\
\hline No. of patients & $\begin{array}{l}\text { More treated on } \\
\text { scene } \\
\text { Few transported } \\
\text { to hospitals }\end{array}$ & $\begin{array}{l}\text { Few treated on } \\
\text { scene } \\
\text { More } \\
\text { transported to } \\
\text { hospitals }\end{array}$ \\
\hline Provider of care & $\begin{array}{l}\text { Medical doctors } \\
\text { supported by } \\
\text { paramedics }\end{array}$ & $\begin{array}{l}\text { Paramedics with } \\
\text { medical } \\
\text { oversight }\end{array}$ \\
\hline Main motive & $\begin{array}{l}\text { Brings the } \\
\text { hospital to the } \\
\text { patient }\end{array}$ & $\begin{array}{l}\text { Brings the } \\
\text { patient to the } \\
\text { hospital }\end{array}$ \\
\hline $\begin{array}{l}\text { Destination for } \\
\text { transported } \\
\text { patients }\end{array}$ & $\begin{array}{l}\text { Direct transport } \\
\text { to hospital } \\
\text { wards ie: } \\
\text { bypassing EDs }\end{array}$ & $\begin{array}{l}\text { Direct transport } \\
\text { to EDs }\end{array}$ \\
\hline $\begin{array}{l}\text { Overarching } \\
\text { organization }\end{array}$ & $\begin{array}{l}\text { EMS is a part of } \\
\text { public health } \\
\text { organization }\end{array}$ & $\begin{array}{l}\text { EMS is a part of } \\
\text { public safety } \\
\text { organization }\end{array}$ \\
\hline
\end{tabular}

There is another model in Emergency Medical Services system beside the Franco-German model and the Anglo-American model called Basic Life Support (BLS) and Advanced Life Support (ALS). Basic Life Support is tightly associated with the 'load and go' philosophy providing non-invasive 
basic interventions and rapid transport to definitive health care facility. Interventions are usually basic and include non-invasive cardiopulmonary resuscitation (CPR), fracture splinting, full immobilization and oxygen administration. On the other hand, the Advanced Life Support (ALS) fits more with the 'stay and stabilize' approach. It includes all the BLS procedures with the addition of invasive procedures such as endotracheal intubation, intravenous line placement, fluid replacement, needle-chest decompression and the administration of controlled and potent medications (Stout et al., 2000). It can be concluded that ALS is much similar with Franco-German model, meanwhile BLS similar with Anglo-American model. However, this study focuses on the former two terminology of emergency medical services model, Franco-German model and Anglo-American model as their applicability in developing countries like Indonesia. Indonesian Ministry of Health had showed the list of medicine in the condition of medical post during disaster whether within or without physician in the team through Regulation of Indonesian Ministry of Health No. 059 Year 2011. The medical supplies management and distribution in both model will be further explained in the Chapter 4 based on these regulation.

Emergency Medical Services team will distinguish the patients especially in disaster into several categories. International disaster colour triage differentiation (Kennedy et al., 1996; Lerner et al., 2008; Ardagh et al., 2012) well known to differentiate patient into several categories by the color in card. There were explained into following statement.

a. Green means minor injuries. Patient treated in ambulatory area (five treatment spaces) of emergency department during incident response.

b. Yellow means moderate injuries. Patients treated in work-up area (15 treatment spaces) of emergency department during incident response.

c. Red means severe injuries. Patients treated in resuscitation area (20 treatment spaces) of emergency department and then monitored during incident response. d. Black means dead or dying patients. Patients not considered for active resuscitation but kept in observation ward (ten beds).

These categorization also implemented in hospital not only in disaster area (Ardagh, 2012). Categorization of patient help in the decision making processes of the doctors or physicians and also will make the system working faster and responsive.

This study aims to develop the model of healthcare aid supply chain during disaster in consideration of Emergency Medical Services as the supporting part on the supply chain. In the model the part of supply chain will be categorized by the disaster life cycle from disaster preparedness, responses, to recovery. The model can be seen in Figure 4.

Beside the model that provide the application of Emergency Medical Services in healthcare aid supply chain during disaster there also several aspects should be considered to maintain better performance in the supply chain. Those several aspects is described in Figure 5 and can be seen in the following points:

1. Demand management;

2. Distribution model; and

3. Coordination.

\section{Demand management}

This aspect will be focused on how the supply chain fulfill the demand of healthcare services during disaster. There will be an rapid increasing on demand with limited supply of medicine, medical staff, physician, and medical equipments. This aspects will be affected by several consideration such as:

- Disaster type \& frequency. Each type of disaster will need different type of medical services. The disaster frequency data in Indonesia can be gathered from BNPB (National Board of Disaster Countermeasure) through DIBI (Main Data of Indonesian Disaster). However, the improvement of the data should be necessary in accordance to existences of inconsistent national data and local data.

- Disaster impact (risk \& hazard). Level of impact will influence the quantity of medical services and type of medical services (medicine, 
including skill of medical staff to face the condition of disaster area and patients during disaster).

- Disaster to diseases mapping means that each specific disaster will produce specific diseases to be cured thus why diseases should be mapped based on type of disaster.

- Diseases to medicine mapping means that after the diseases already be mapped then the data of medicine needed can be gathered to list the demand of medicine in a specific disaster.

- Demand estimation means that if the type of medicine in specific disaster had been known then the demand of medicine can be estimated. It also means that if the type of disaster and level of impact had been known then the demand of medical personnel can also be known and estimated.

\section{Distribution model}

This aspect will be focused on how the healthcare aid collected and disseminated to patients from disaster. It will be started from funding, sourcing, making or producing, up to delivering.

- Funding means the activity will be about the financial support to provide healthcare aid during disaster. It can be collected from private companies or funded by government. Funding activities should be controlled in the good integrity mechanism to avoid chaotic and corrupted funding system.

- Sourcing means the activity will be about the vendor selection (i.e. hospital, pharmacies) to provide medicine and medical staff to help patients from disaster.

- Make means the production processes of medicine including their storage processes or service providing processes of medical services (medical staff and their medical equipment) should be well maintained and in its good quality in order to help the patients from disaster.

- Deliver means that the transportation or mobilization processes of medicine and medical services to provide healthcare aid for patients from disasters.

\section{Coordination}

This aspect will be focused on how the participating parts on healthcare aid supply chain coordinated to perform better medical services to patients from disaster. There are several consideration such as:

- Actors included hospital, pharmacies, medical staff, government, community, and other parts involved in disaster resilience especially in providing healthcare aid.

- Information to support demand estimation for supplying medical services to patients from disaster. The information also will support infrastructure development after disaster.

- Infrastructure to support medical services during disaster such as road and supporting part (i.e. fire fighter forces, army forces).

- Funding need coordination to avoid chaotic and corrupted system during disaster.

Indonesian government actually already maintain the system for management of medicine by published a regulation to overcome all aspects that explained in this study. Management of medicine based on the Regulation of Ministry of Health Number 059, 2011 as below:

- Requirement planning

- Provision of drugs and medical supplies

- Storage and distribution

- Use and control

- Recording, evaluating, and reporting

- Destruction and disposal

There are standard in those aspects that should be considered carefully. The standard of storage should be conducted in the place which is suitable with the requirements and managed by qualified officers. Distribution system can be seen from the figure on Request \& Distribution of Drugs \& Medical Supplies. Recording and reporting are able through figure of flow on reporting during emergency response phase.

Indonesian government also developed several considerations regarding provision of drugs and medical supplies also based on the Regulation of Ministry of Health Number 059, 2011. The considerations as follow:

- Type of disaster

- Disaster area and the number of affected victims

- Current medical stock 


\subsection{Human Resource and Transportation}

Model that described in Figure 3 show that what kind of human resources and transportation needed especially during disaster responses. Human resources such as doctors and/or paramedics are needed in disaster responses phase. If the Emergency Medical Service System adopt the French-German model then doctors and paramedics will be needed, otherwise if the Emergency Medical Service System adopt the Anglo-American model then only paramedics will be needed as main human resources. In the transportation, ambulance will help the doctors and/or paramedics to mobilize from and/or to disaster area. In the several developed countries, air support will provided by helicopter as another transportation mode. In Figure 1 and 2 can be concluded that in French-German model there is possibility the number of doctors can be larger and the number of transportation mode can be smaller, meanwhile in Anglo-American model there is possibility the number of doctors can be smaller and the number of transportation mode can be larger. This conclusion can be withdrawn as similar objective function of both model which are to increasing number of surviving patients.

\subsection{Medicine and Medical Equipment}

As explained before, one aspect should be considered in healthcare aid supply chain mapping is common type of diseases in each type of disaster should be known. In Table 1, the information of common diseases in several type of disasters had been mentioned in the Regulation of Indonesian Ministry of Health No.059 Year 2011.

\begin{tabular}{|l|l|l|}
\hline No. & $\begin{array}{c}\text { Disaster } \\
\text { Type }\end{array}$ & \multicolumn{1}{|c|}{ Diseases } \\
\hline 1 & Flood & $\begin{array}{l}\text { Diarrhea, Dermatitis (skin disease), Acute } \\
\text { Respiratory Infection (ARI) (pneumonia } \\
\text { and non pneumonia) }\end{array}$ \\
\hline 2 & $\begin{array}{l}\text { Volcano } \\
\text { Eruption }\end{array}$ & $\begin{array}{l}\text { Acute Respiratory Infection (ARI), } \\
\text { Diarrhea, Conjunctivitis, Burn wounds }\end{array}$ \\
\hline 3 & Fire at Forest & $\begin{array}{l}\text { Acute Respiratory Infection (ARI), Burn } \\
\text { wounds }\end{array}$ \\
\hline 4 & $\begin{array}{l}\text { Fire at } \\
\text { Residential } \\
\text { Area }\end{array}$ & $\begin{array}{l}\text { Acute Respiratory Infection (ARI), Burn } \\
\text { wounds }\end{array}$ \\
\hline
\end{tabular}

\begin{tabular}{|l|l|l|}
\hline 5 & Conflict & $\begin{array}{l}\text { Bruises, Cuts, Gash wounds, Bone } \\
\text { Fracture }\end{array}$ \\
\hline 6 & Landslide & $\begin{array}{l}\text { Bone Fracture, Bruises, } \\
\text { Cuts, Bone Fracture }\end{array}$ \\
\hline 7 & Tsunami & Diarrhea, ARI, Bruises, Cuts \\
\hline 8 & Earthquake & $\begin{array}{l}\text { Bruises, Cuts, } \\
\text { Bone Fracture }\end{array}$ \\
\hline
\end{tabular}

Table 1 Type of Disasters and Diseases

(Source: Regulation of Indonesian Ministry of Health No.059 Year 2011)

The French-German model and Anglo-American model also indirectly mentioned in the regulation. The information explained in the regulation is the list of medicine supplies needed during disaster. Uniquely, without mention specifically about two model formerly mentioned, the regulation distinguish the list into two type. There are list of medicine supplies for medical post without physician or doctor and list of medicine supplies for medical post with physician or doctor. There are two possibilities why the regulation distinguish the list into two terms. First, there is possibility that the regulation already recognized both model in Emergency Medical Service system. Second, there is also possibility that the regulation realize that there is some lack of physician in several medical post or clinic in rural area. However, those two lists are important to be showed in this research to give knowledge what kind of medicine is needed during disaster and how prepared the medical system in Indonesia faces a disaster. The regulation itself noted that the information was adopted from a book entitled New Emergency Health KITs published by WHO. Table 2 will show the list of medicine needed if there is no doctor or physician in the medical post or clinic. Meanwhile, Table 3 will explain the list of medicine needed if the medical post or clinic supported by doctor or physician.

\begin{tabular}{|l|l|c|c|}
\hline No. & \multicolumn{1}{|c|}{ Name of Drugs } & $\begin{array}{c}\text { Smallest } \\
\text { Unit }\end{array}$ & $\begin{array}{c}\text { Administr } \\
\text { ation }\end{array}$ \\
\hline 1 & Paracetamol Tablet $500 \mathrm{mg}$ & Tablet & Oral \\
\hline 2 & Paracetamol Tablet $100 \mathrm{mg}$ & Tablet & Oral \\
\hline 3 & Paracetamol Syrup & Bottle & Oral \\
\hline 4 & Vitamin C Tablet $50 \mathrm{mg}$ & Tablet & Oral \\
\hline 5 & Antacid Tablet & Tablet & Oral \\
\hline 6 & Oralite Rehydration Salt & Sachet & Oral \\
\hline
\end{tabular}




\begin{tabular}{|l|l|c|c|}
\hline 7 & Ferrous sulfate tablet & Tablet & Oral \\
\hline 8 & Povidone Iodine solution $10 \%$ & Bottle & Topical \\
\hline 9 & Ointment $2-4$ & Pot & Topical \\
\hline 10 & Cough Syrup & Bottle & Oral \\
\hline 11 & Gauze $4 \times 15 \mathrm{~cm}$ & Roll & Topical \\
\hline 12 & Cotton ball & Pack & Topical \\
\hline 13 & Bandage & Roll & Topical \\
\hline 14 & Vitamin B Complex & Tablet & Oral \\
\hline 15 & Glyceryl Guaiacolate & Tablet & Oral \\
\hline 16 & Eucalyptus Oil & Bottle & Topical \\
\hline 17 & Activated Charcoal & Tablet & Oral \\
\hline
\end{tabular}

Table 2 List of Medicine in Medical Post Without Physician

(Source: Regulation of Indonesian Ministry of Health No.059 Year 2011)

\subsection{Assessment of Reference Model}

Mainly there are three phases in current healthcare distribution system during disaster in Indonesia (Figure 6). Firstly, the pharmaceutical and medical support distribution phase from national buffer stock during disaster. In this stage, all distribution will be responsible by Indonesian Directorate General of Pharmaceutical and Medical to support disaster victims. This procedure will be proceed based on rapid health assessment team request and based on number of victims and type of disease. Secondly, the distribution phase from province to district. If the district has buffer stock and receive support from other source, the distribution can be proceed based on request from head of district public health care office. The data request based on the number of victims and the type of disease. Thirdly, the distribution process from district to remote hospital, field hospital, Indonesian armed force healthcare facility and private healthcare facility. In this phase, all medicine and medical support distribution will handle by district public health office to the healthcare unit based on the data of victims and disease type. This distribution will be proceed directly in the same day after receive request from healthcare facility unit.

The paramedic personnel will use stock card form to record and control healthcare inventory during emergency response. All healthcare inventory received, usage and latest stock should report daily, weekly and monthly. This report process will be evaluate during disaster response phase (Figure 7).

\begin{tabular}{|c|c|c|c|}
\hline No. & Name of Drugs & $\begin{array}{c}\text { Smallest Unit/ } \\
\text { Type }\end{array}$ & Price \\
\hline 1 & $\begin{array}{l}\text { Antalgin Tablet } 500 \\
\text { mg }\end{array}$ & Tablet/Oral Solid & Rp. 250,- \\
\hline 2 & $\begin{array}{l}\text { Paracetamol Tablet } \\
500 \mathrm{mg}\end{array}$ & Tablet/Oral Solid & Rp. 141,75 \\
\hline 3 & $\begin{array}{l}\text { Paracetamol Tablet } \\
100 \mathrm{mg}\end{array}$ & Tablet/Oral Solid & Rp. 56,57 \\
\hline 4 & Paracetamol Syrup & \begin{tabular}{|l} 
Tablet/Oral \\
Liquid
\end{tabular} & Rp. 3.105,- \\
\hline 5 & $\begin{array}{l}\text { Vitamin } \mathrm{C} \text { tablet } 50 \\
\mathrm{mg}\end{array}$ & Tablet/Oral Solid & Rp. 182,- \\
\hline 6 & Antacid Tablet & Tablet/Oral Solid & Rp. 218,70 \\
\hline 7 & $\begin{array}{l}\text { Oralite Rehydration } \\
\text { Salt }\end{array}$ & Sachet/Oral Solid & Rp. 541,40 \\
\hline 8 & ACT & Tablet/Oral Solid & Rp. $1.856,25$ \\
\hline 9 & Ferrous Sulfate & Tablet/Oral Solid & $\operatorname{Rp} 35,42$ \\
\hline 10 & Povidone Iodine $10 \%$ & $\begin{array}{l}\text { Bottle } 30 \mathrm{ml} / \\
\text { Topical Liquid }\end{array}$ & Rp. 3.240,- \\
\hline 11 & Ointment 2-4 & $\begin{array}{l}\text { Pot 30g/Topical } \\
\text { Semisolid }\end{array}$ & Rp. $1.659,38$ \\
\hline 12 & Black cough syrup & \begin{tabular}{|l|} 
Bottle $100 \mathrm{ml} /$ \\
Oral Liquid
\end{tabular} & Rp. 1.931,- \\
\hline \multicolumn{4}{|c|}{ Anesthetic } \\
\hline 13 & Lidocaine injection & \begin{tabular}{|l} 
Ampoule/ \\
Parenteral Liquid
\end{tabular} & Rp. $1.363,50$ \\
\hline \multicolumn{4}{|c|}{ Anti-allergy } \\
\hline 14 & $\begin{array}{l}\text { Hydrocortisone } \\
\text { Cream } 2 \%\end{array}$ & $\begin{array}{l}\text { Tube/ } \\
\text { Topical Semisolid }\end{array}$ & Rp. 4.050,- \\
\hline 15 & Prednisolone tab $5 \mathrm{mg}$ & Tablet/Oral Solid & Rp. 76,28 \\
\hline 16 & $\begin{array}{l}\text { Chlorpheniramine } \\
\text { maleate }\end{array}$ & Tablet/Oral Solid & Rp. 30,88 \\
\hline \multicolumn{4}{|c|}{ Anticonvulsant } \\
\hline 17 & $\begin{array}{l}\text { Diazepam inj. } 5 \\
\mathrm{mg} / \mathrm{ml}\end{array}$ & \begin{tabular}{|l} 
Ampoule/ \\
Parenteral Liquid
\end{tabular} & Rp. 25.000,- \\
\hline 18 & $\begin{array}{l}\text { Phenobarbital tab } 30 \\
\text { mg }\end{array}$ & Tablet/Oral Solid & Rp. 87,62 \\
\hline \multicolumn{4}{|c|}{ Anti-infectives } \\
\hline 19 & $\begin{array}{l}\text { Amoxicillin Dry } \\
\text { Syrup }\end{array}$ & \begin{tabular}{|l} 
Bottle/Oral \\
Liquid
\end{tabular} & Rp. 4.995,- \\
\hline 20 & $\begin{array}{l}\text { Amoxicillin Caps } 250 \\
\mathrm{mg}\end{array}$ & \begin{tabular}{|l} 
Capsule/ \\
Oral Solid \\
\end{tabular} & Rp. 363,15 \\
\hline 21 & $\begin{array}{l}\text { Amoxicillin Caps } 500 \\
\mathrm{mg}\end{array}$ & $\begin{array}{l}\text { Capsule/ } \\
\text { Oral Solid } \\
\end{array}$ & Rp. 514,35 \\
\hline 22 & $\begin{array}{l}\text { Chloramphenicol } \\
\text { Caps } 250 \mathrm{mg} \\
\end{array}$ & $\begin{array}{l}\text { Capsule/ } \\
\text { Oral Solid } \\
\end{array}$ & Rp. 359,78 \\
\hline 23 & $\begin{array}{l}\text { Metronidazole tab } 250 \\
\mathrm{mg}\end{array}$ & \begin{tabular}{|l} 
Tablet/ \\
Oral Solid \\
\end{tabular} & Rp. 193,05 \\
\hline 24 & Cotrimoxazole & \begin{tabular}{|l} 
Tablet/ \\
Oral Solid
\end{tabular} & Rp. 222,75 \\
\hline
\end{tabular}


Table 3 List of Medical Post With Physician

(Source:Regulation of Indonesian Ministry of Health No.059 Year 2011)

\section{Conclusion}

The need of Emergency Medical Services (EMS) in healthcare aid supply chain for low impact and high frequent disaster is inevitable. Through limited resources of doctors and ambulance or transportation modes, EMS will provide medical services for low impact disaster such as fire and flood effectively. The team of EMS is simple and easy to be adopted. The problem is there are no specific model had been used of EMS in Indonesia. There are two contrary model had been known by worldwide, French-German model with the concept of 'bring the hospital to the patient' and Anglo-American model with the concept of 'bring the patient to the hospital'. This study provide the necessary information about both of the model and contextualized to Indonesian disaster management problems through healthcare aid supply chain mapping. There is some aspects should be considered to adopt the model in the future. There are: (1) demand management; (2) distribution model; and (3) coordination. Demand management focused on how to estimate demand of healthcare aid during disaster by the data which Indonesian Government had such as data of disaster frequency, data of disaster type, data of diseases type for each disaster type, and data of medicine. Distribution model focused on how to procurement system of healthcare aid should be conducted from its funding, sourcing, making, until its delivery or transport. Lastly, coordination between government, hospital, and community should be well arranged in a transparent and full of integrity system to avoid chaotic and corrupted disaster management in the future to come. By providing this model, further research can be conducted by starting considering to mapped cost effectiveness of the EMS model implemented in Indonesia with consideration of transportation cost, medicine price (this study already provide the list of medicine needed with its prices), and infrastructure condition in Indonesia. In another perspectives, different research also can be conducted to mapping the needs of preparing the model to be implemented in Indonesia.

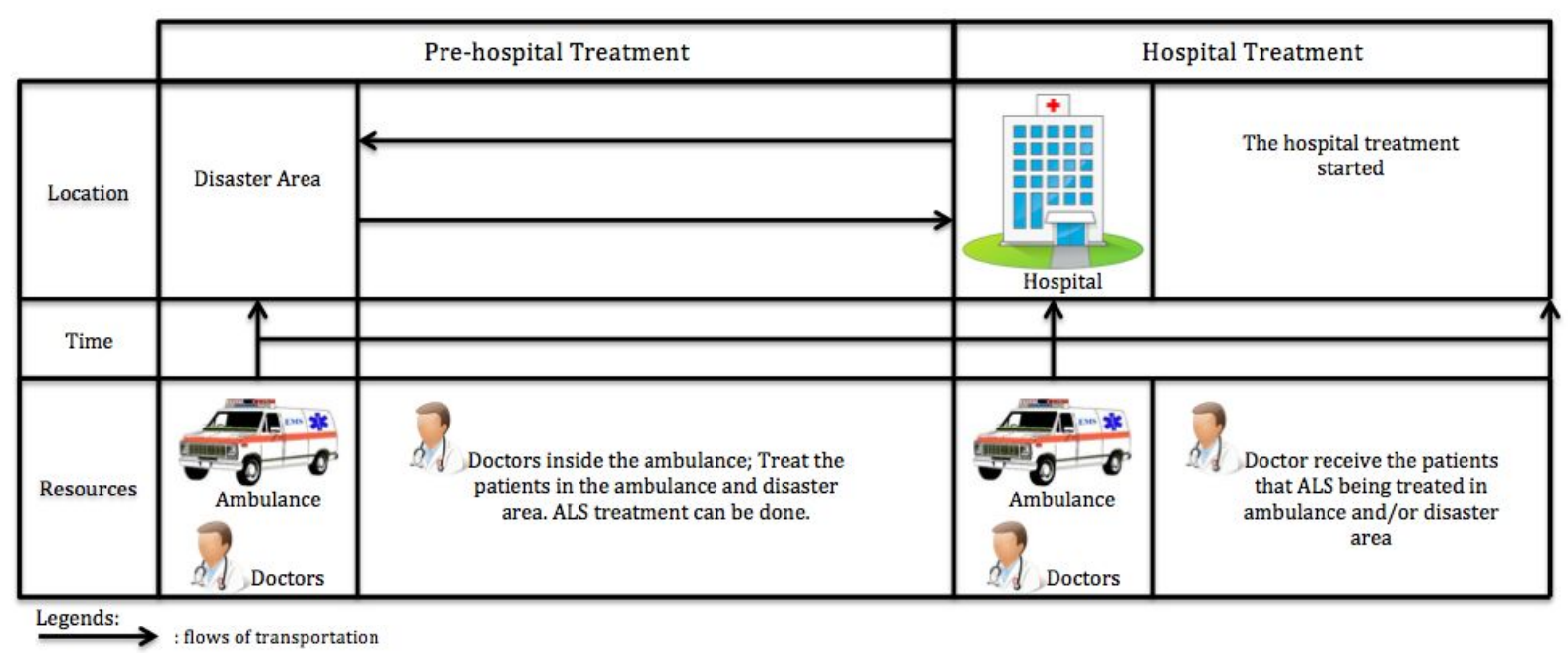

Figure 2. The French-German model 


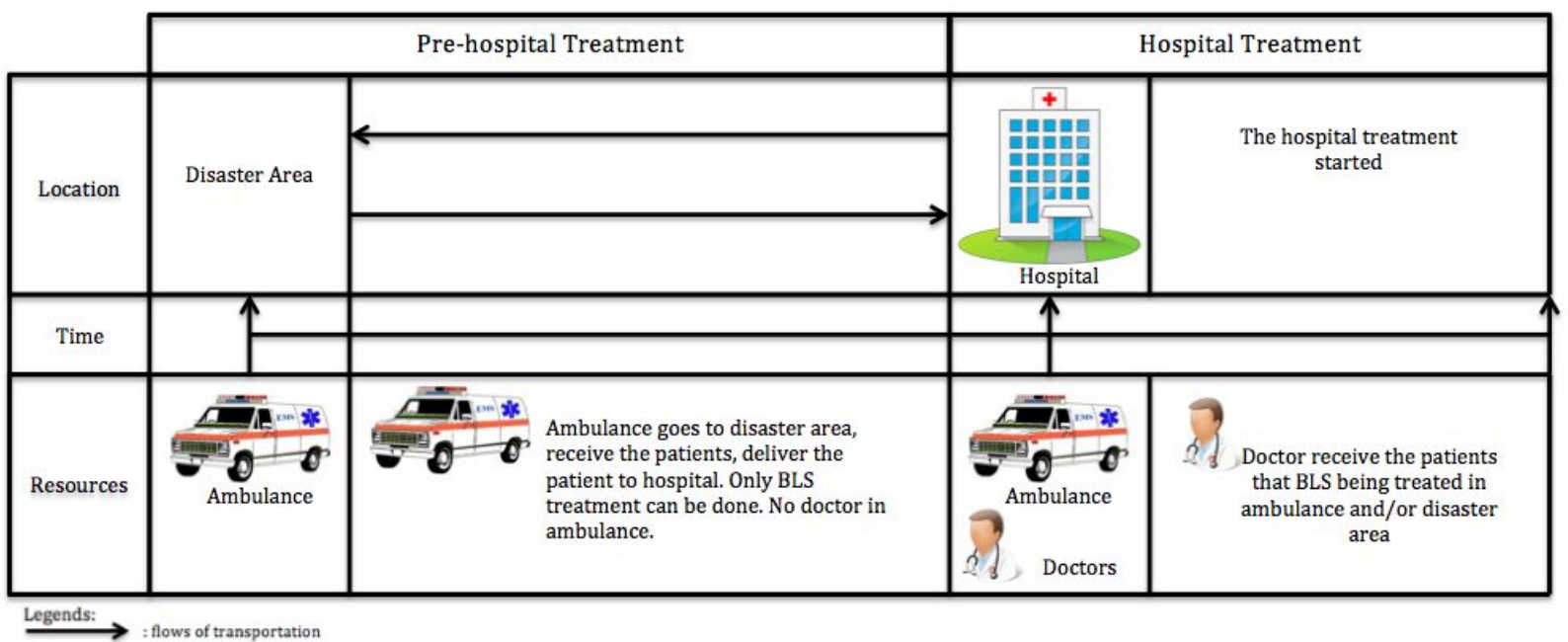

Figure 3. Anglo-American model

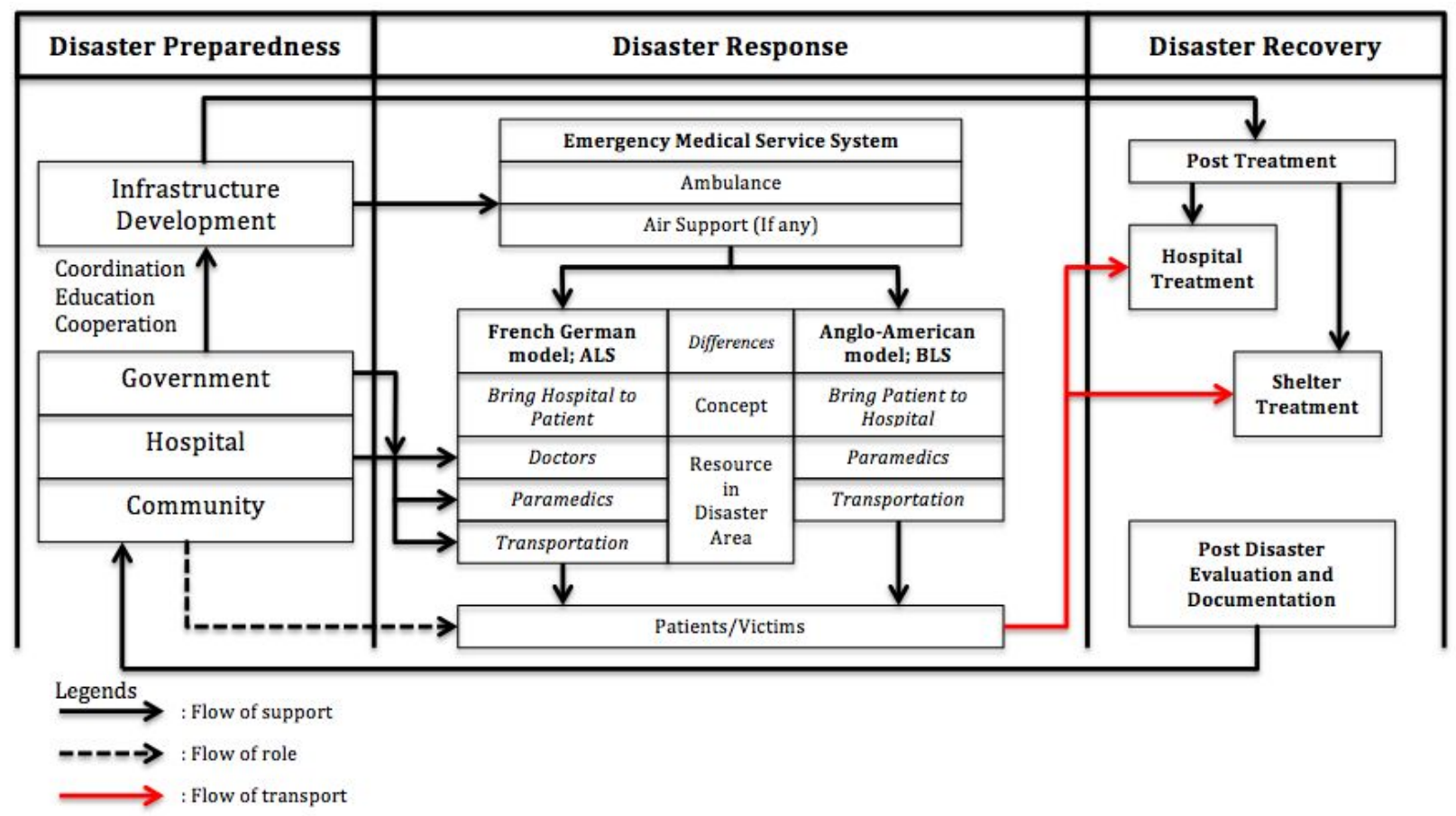

Figure 4. The Model of Healthcare Aid Supply Chain Based on Disaster Life Cycle in which EMS Become Main Role in Disaster Response 


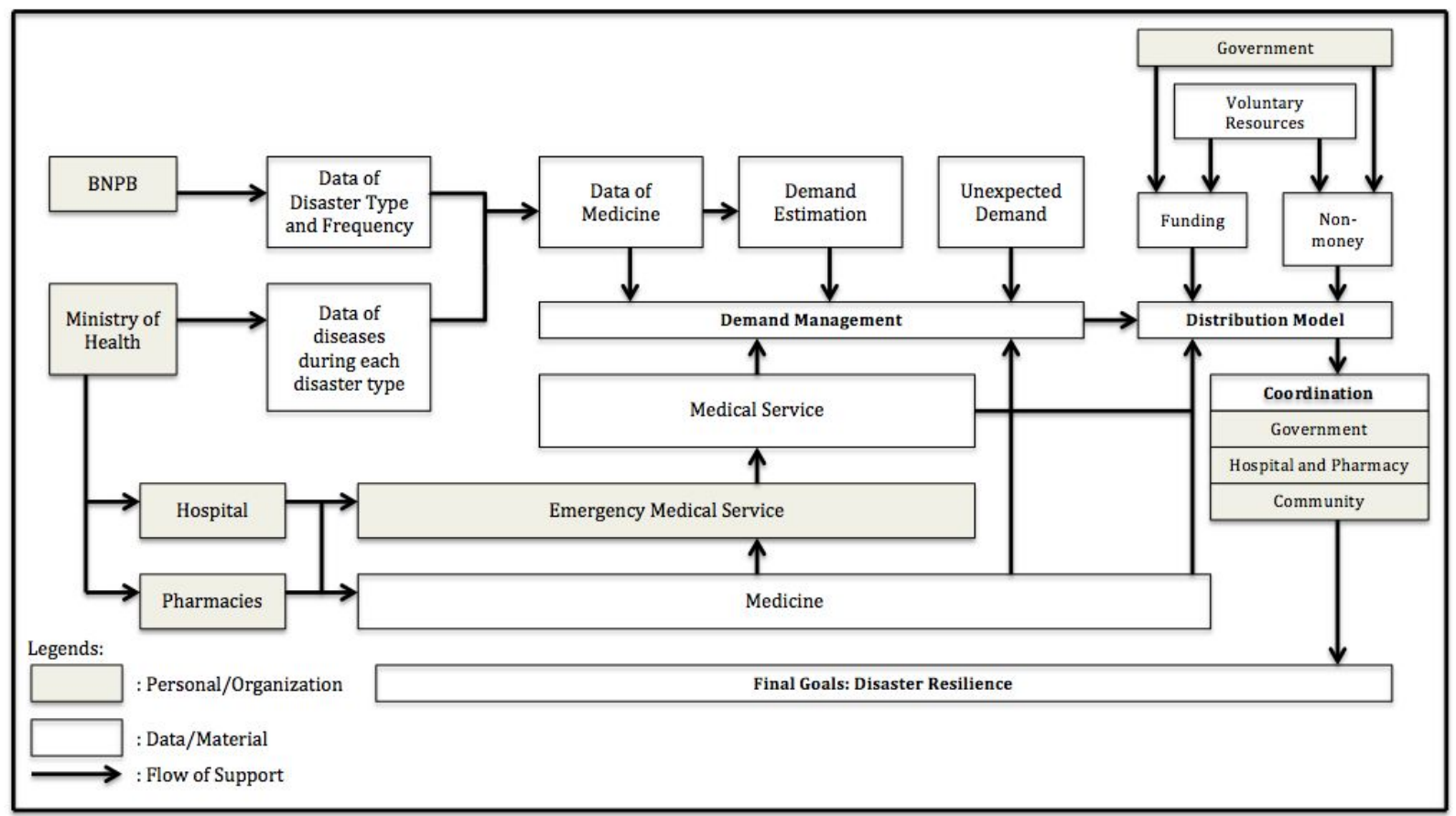

Figure 5. Aspects, Participating Parts, and Material/Data Flow of Healthcare Aid Supply Chain in Indonesia. BNPB is acronym for National Board of Disaster Countermeasure which responsible to manage disaster resilience and developed by Indonesian Government.

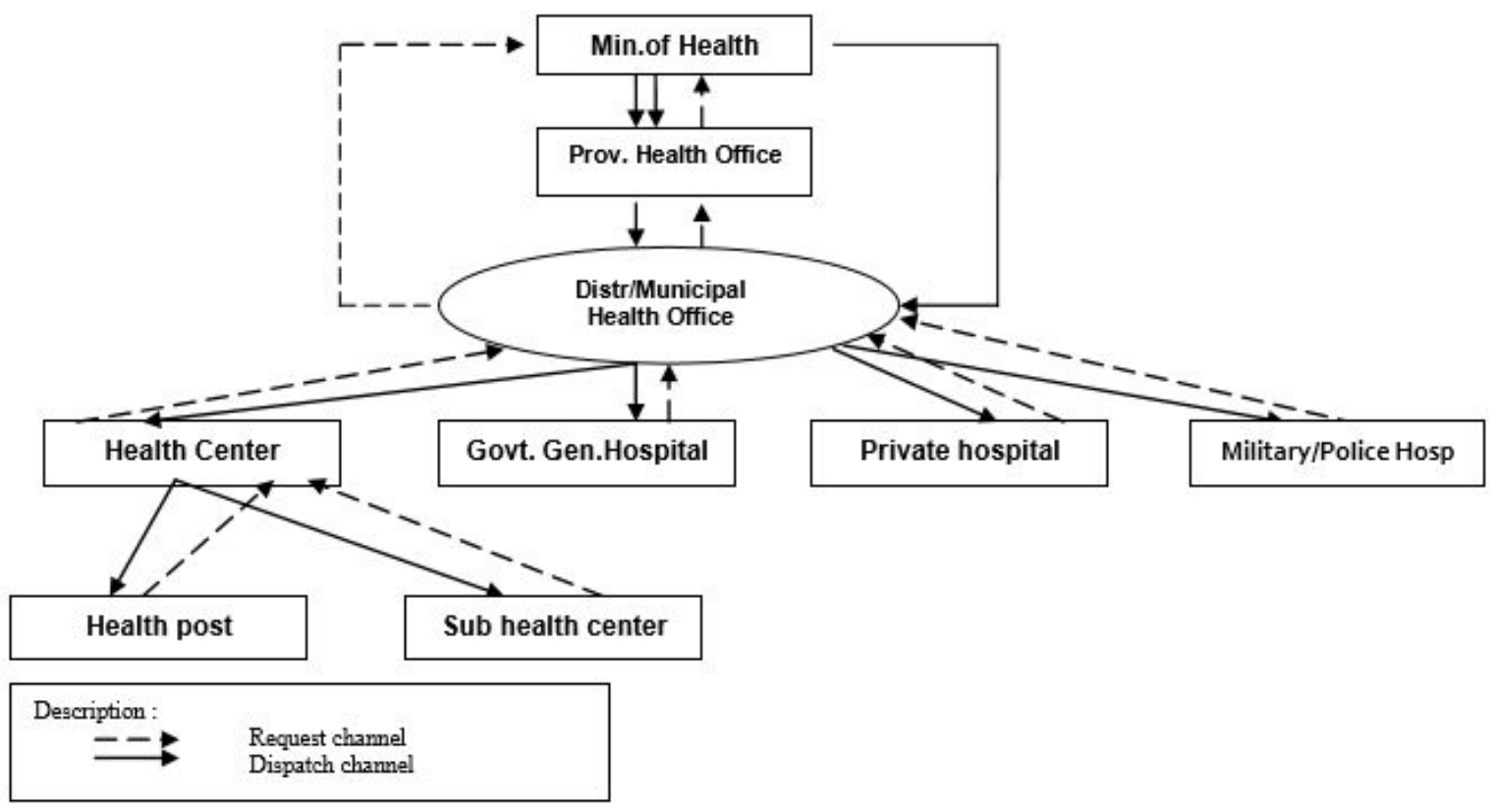

Figure 6. Request \& Distribution of Drugs \& Medical Supplies

(Source: Regulation of Indonesian Ministry of Health No.059 Year 2011) 


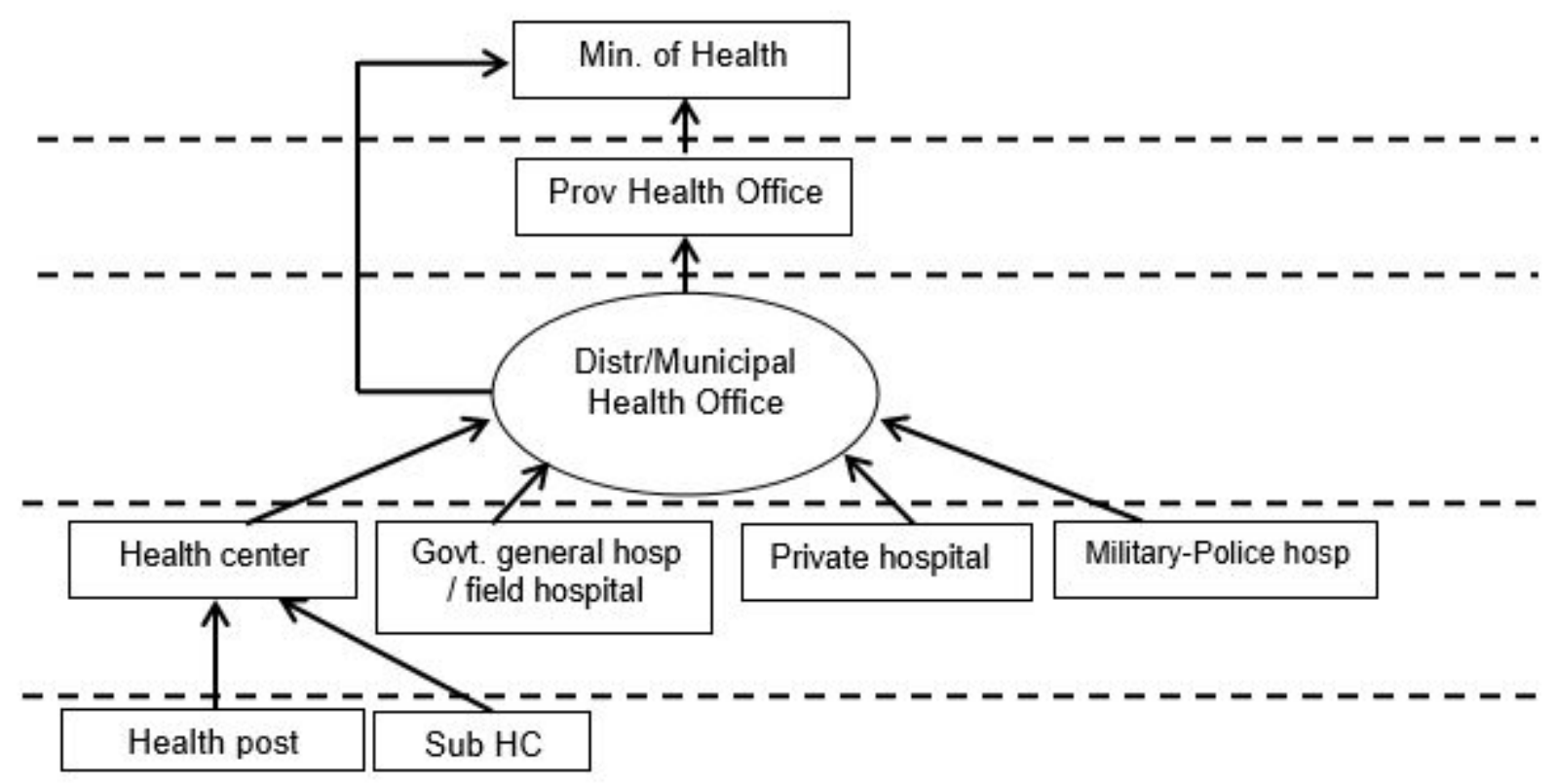

Figure 7. Flow on reporting during disaster response phase

(Source: Regulation of Indonesian Ministry of Health No.059 Year 2011)

\section{References}

Al-Shaqsi, S. (2010). Models of international emergency medical service (EMS) systems. Oman medical journal, 25(4), 320

Ardagh, M. W., Richardson, S. K., Robinson, V., Than, M., Gee, P., Henderson, S., ... \& Deely, J. M. (2012). The initial health-system response to the earthquake in Christchurch, New Zealand, in February, 2011. The Lancet, 379(9831), 2109-2115.

Bisri.M.F., (2013). Examining inter-organizational network during emergency response of West Java earthquake 2009, Indonesia. Procedia Environmental Sciences 17. 889-898.

Carranza, E.M., Wibowo.H., Barrit, S.D., Sumintadireja. P., (2008). Spatial data analysis and integration for regional-scale geothermal potential mapping, West Java, Indonesia Geothermics 37. 267-299

Healslip, G.; Mangan, J.; Lalwani, C. (2010) Modeling a Humanitarian Supply Chain Using the Structured Analysis and Design

Technique (SADT). University of Hull Logistics Institute. UK.

Kennedy, K., Aghababian, R. V., Gans, L., \& Lewis, C. P. (1996). Triage: techniques and applications in decisionmaking. Annals of Emergency Medicine, 28(2), 136-144. 
Kölsch, F., Fricke, K., Mahler, C., Damanhuri, E., (2005). Stability of landfills - The Bandung disaster. In: Proceedings of the 10th International Landfill Symposium, Cagliari, Italy.

Kovacs, G \& Spens, K.M (2007). Humanitarian logistics in disaster relief operations. International Journal of Physical Distribution and Logistics Management Vol. 37 No 2 pp 99 - 114

Lerner, E. B., Schwartz, R. B., Coule, P. L., Weinstein, E. S., Cone, D. C., Hunt, R. C., ... \& Hammond, J. (2008). Mass casualty triage: an evaluation of the data and development of a proposed national guideline. Disaster medicine and public health preparedness, 2(S1), S25-S34.

Muhari.A., Diposaptono, S., Imamura, F., (2007). Toward an Integrated Tsunami Disaster Mitigation: Lessons Learned from Previous Tsunami Events in Indonesia. Journal of Natural Disaster Science, Volume 29, Number 1, pp13-19 13.

Sahebi, I.G., Arab, A \& Moghadam, R.S. (2016). Analyzing the barriers to humanitarian supply chain management: A case study of the Tehran Red Crescent Societies. International Journal of Disaster Risk Reduction

Scholten, Kirstin, Pamela Sharkey Scott, and Brian Fynes. 2010. "(Le)agility in humanitarian aid (NGO) supply chains." International Journal of Physical Distribution \& Logistics Management 40 (8/9): 623-635.

Stout, J., Pepe, P. E., \& Mosesso, V. N. (2000). A LL-ADVANCED LIFE SUPPORT VS TIERED-RESPONSE AMBULANCE SYSTEMS. Prehospital Emergency Care, 4(1), 1-6.

Thomas, A.S. and Kopczak, L.R. (2005) From Logistics to Supply Chain Management: The Path Forward in the Humanitarian Sector. Fritz Institute.

Vaillancourt, A. (2016). Kit management in humanitarian supply chains. International Journal of Disaster Risk Reduction.

Vitoriano et al. (2013.), Decision Aid Models for Disaster Management and Emergencies, Atlantis Computational Intelligence Systems 7, Atlantis Press

Wassehhove, LN. V. (2005). Humanitarian Aid Logistics: supply chain management in high gear. Journal of the Operational Research Society 57, pp 475-489

Yadav, D.K \& Barve, A. (2014). Analysis of critical success factors of humanitarian supply chain: an application of interpretive structural modelling. International Journal of Disaster Risk Reduction 12 pp 213 - 225 